\title{
Parapedocotyle prolatili gen. n. et sp. n., a representative of a new subfamily of the Diclidophoridae (Monogenea), a gill parasite of Prolatilus jugularis (Teleostei: Pinguipedidae) from Chile
}

\author{
Marcelo E. Oliva ${ }^{1}$, Fabiola A. Sepulveda $^{1,2}$ and M. Teresa González ${ }^{1}$ \\ ${ }^{1}$ Instituto de Ciencias Naturales Alexander von Humboldt, Facultad de Ciencias del Mar y Recursos Biológicos, Universidad de \\ Antofagasta, Antofagasta, Chile; \\ ${ }^{2}$ Programa Doctorado en Ciencias Aplicadas, Facultad de Ciencias del Mar y Recursos Biológicos, Universidad de Antofagasta \\ Antofagasta, Chile
}

\begin{abstract}
Parapedocotylinae, a new subfamily, is proposed to accommodate the gen. n. et sp. n. Parapedocotyle prolatili (Monogenea: Diclidophoridae), a gill parasite of the Pacific sandperch, Prolatilus jugularis (Valenciennes) (Pinguipedidae) from northern Chile $\left(30^{\circ} 56^{\prime} \mathrm{S} ; 7^{\circ} 20^{\prime} \mathrm{W}\right)$. Among the Diclidophoridae Cerfontaine, 1895, the species of the Pedocotylinae Yamaguti, 1963 are unique by bearing the first pair of clamps (most posteriorly) in a haptoral projection. Pedocotyle MacCallum, 1913, the only genus in the Pedocotylinae, is characterised by the first pair of clamps non-pedunculate, modified and non-functional, without accessory suckers, and clamps of pairs 2-4 being pedunculate and functional. In contrast, the first pair of clamps in Parapedocotyle is well developed and functional at the terminal end of a long haptoral appendix and having clamp pairs 2-4 pedunculated, modified and apparently not functional. Seminal receptacle is preovarian in Parapedocotyle in opposition to its postovarian position in Pedocotyle. These differences justified the erection of the new subfamily Parapedocotylinae. The new subfamily is also supported by genetic analyses (18S rDNA, 28S rDNA and coxl sequences) demonstrating that the Pedocotylinae and Parapedocotylinae belong to different clades in the Diclidophoridae.
\end{abstract}

Keywords: Monogenea, new subfamily, Parapedocotylinae, marine fish, Chile

Among the Diclidophoridae Cerfontaine, 1895, the Pedocotylinae Yamaguti, 1963 is unique because of the structure and arrangement of the clamps: "with three pair of pedunculate clamps just behind testicular region; last pair much smaller" Yamaguti (1963). This author did not consider that the last pair (most posterior) is smaller and deeply modified and non-functional, as described by Sproston (1946) and later by Luque-Alejos and Iannacone-Oliver (1989).

During a survey of parasites from marine fishes along the northern Chilean coast, specimens of an undescribed diclidophorid were found on the gills of the Pacific sandperch Prolatilus jugularis (Valenciennes) (Pinguipedidae) caught near Coquimbo, northern Chile. Characteristics of our specimens showed a slight morphological similarity with Pedocotyle MacCallum 1913, specifically the general arrangement of the haptor, but strongly differed in that the first pair of clamps, which is deeply modified and non-functional in Pedocotyle, is non-modified in our specimens. This was an indication that our specimens may belong to a new subfamily of the Diclidophoridae
In order to assess the position of the new species in the Diclidophoridae we obtained and sequenced specimens of Pedocotyle bravoi Luque-Alejos et Iannacone-Oliver, 1989 and P. annakohni Luque-Alejos et Iannacone-Oliver, 1989 as well of others diclidophorids from northern Chile: Choricotyle anisotremi Oliva, 1987, Paraeurysorchis sarmientoi (Tantalean, 1974) and the microcotylid Paramicrocotyle sp. A few sequences for other diclidophorids and the mazocraeid Kuhnia scombri (Kuhn, 1829) available in the GenBank database were also included in the analysis.

\section{MATERIALS AND METHODS}

In 2006, 50 specimens of the Pacific sandperch, Prolatilus jugularis (Perciformes: Pinguipedidae), were obtained from local fishermen near Coquimbo, northern Chile $\left(30^{\circ} 56\right.$ 'S; $71^{\circ} 20^{\prime} \mathrm{W}$ ); of those 38 were infected by specimens of a hitherto unknown diclidophorid. Worms were removed from the gills, fixed in AFA (ethanol: formalin: acetic acid), stained with hematoxyline-eosin or Gomori's trichrome, dehydrated in alcohol series from $70 \%$ to $100 \%$, cleared in acid alcohol and mounted 
Table 1. List of sequences analysed.

\begin{tabular}{|c|c|c|c|c|c|c|}
\hline Parasite species & $\begin{array}{l}\text { Family and } \\
\text { subfamily* }\end{array}$ & Host species & Origin & GenBank accession & Gene & Source \\
\hline Parapedocotyle prolatili sp. n. & DICL, PARA & $\begin{array}{l}\text { Prolatilus jugularis } \\
\text { (Valenciennes) }\end{array}$ & Chile & KJ397731 & $28 S$ & Present study \\
\hline Parapedocotyle prolatili sp. $\mathrm{n}$. & DICL, PARA & Prolatilus jugularis & Chile & KJ397725 & $18 S$ & Present study \\
\hline Parapedocotyle prolatili sp. $\mathrm{n}$. & DICL, PARA & Prolatilus jugularis & Chile & $\begin{array}{c}\text { KJ794212, KJ794214, } \\
\text { KJ794216, KJ794218, } \\
\text { KJ794219 }\end{array}$ & $\operatorname{cox} 1$ & Present study \\
\hline $\begin{array}{l}\text { Pedocotyle annakohni } \\
\text { Luque-Alejos et Iannacone-Oliver, } \\
1989\end{array}$ & DICL, PEDO & Stellifer minor (Tschudi) & Peru & KJ397728 & $28 S$ & Present study \\
\hline Pedocotyle annakohni & DICL, PEDO & Stellifer minor & Peru & KJ397722 & $18 S$ & Present study \\
\hline $\begin{array}{l}\text { Pedocotyle bravoi } \\
\text { Luque-Alejos et Iannacone-Oliver, } \\
1989\end{array}$ & DICL, PEDO & Stellifer minor & Peru & KJ397729 & $28 S$ & Present study \\
\hline Pedocotyle bravoi & DICL, PEDO & Stellifer minor & Peru & KJ397723 & $18 S$ & Present study \\
\hline Pedocotyle bravoi & DICL, PEDO & Stellifer minor & Peru & KJ794208-KJ794211 & $\operatorname{cox} 1$ & Present study \\
\hline $\begin{array}{l}\text { Paraeurysorchis sarmientoi } \\
\text { (Tantalean, 1974) }\end{array}$ & DICL, EURY & $\begin{array}{l}\text { Seriolella violacea } \\
\text { Guichenot }\end{array}$ & Chile & KJ397730 & $28 S$ & Present study \\
\hline Paraeurysorchis sarmientoi & DICL, EURY & Seriolella violacea & Chile & KJ397724 & $18 S$ & Present study \\
\hline Paraeurysorchis sarmientoi & DICL, EURY & Seriolella violacea & Chile & KJ794213-2KJ794217 & $\operatorname{cox} 1$ & Present study \\
\hline $\begin{array}{l}\text { Choricotyle anisotremi } \\
\text { Oliva, } 1987\end{array}$ & DICL, CHOR & $\begin{array}{l}\text { Anisotremus scapularis } \\
\text { (Tschudi) }\end{array}$ & Chile & KJ397727 & $28 S$ & Present study \\
\hline Choricotyle anisotremi & DICL, CHOR & Anisotremus scapularis & Chile & KJ397721 & $18 S$ & Present study \\
\hline Choricotyle anisotremi & DICL, CHOR & Anisotremus scapularis & Chile & KJ794205-KJ794207 & $\operatorname{cox} 1$ & Present study \\
\hline $\begin{array}{l}\text { Choricotyle cf. chrysophryii } \\
\text { (Beneden et Hesse, 1863) }\end{array}$ & DICL, CHOR & Pagellus acarne (Risso) & France & AF311705 & $28 S$ & Jovelin and Justine (2001) \\
\hline $\begin{array}{l}\text { Diclidophora minor } \\
\text { (Olsson, 1876) }\end{array}$ & DICL, DNAE & $\begin{array}{l}\text { Micromesistius poutassou } \\
\text { (Risso) }\end{array}$ & UK & AF382048 & $28 S$ & Olson et al. (2002) \\
\hline $\begin{array}{l}\text { Diclidophora denticulata } \\
\text { (Olsson, 1876) }\end{array}$ & DICL, DNAE & $\begin{array}{l}\text { Pollachius virens } \\
\text { (Linnaeus) }\end{array}$ & UK & AF382047 & $28 S$ & Olson et al. (2002) \\
\hline $\begin{array}{l}\text { Diclidophora luscae capelanii } \\
\text { (van Beneden et Hesse, 1863) }\end{array}$ & DICL, DNAE & $\begin{array}{l}\text { Trisopterus luscus } \\
\text { capelanus (Lacepede) }\end{array}$ & France & AF311704 & $28 S$ & Jovelin and Justine (2001) \\
\hline Paramicrocotyle sp. & MICR, MNAE & $\begin{array}{l}\text { Pinguipes chilensis } \\
\text { Valenciennes }\end{array}$ & Chile & KJ794215 & $\operatorname{cox} 1$ & Present study \\
\hline $\begin{array}{l}\text { Kuhnia scombri } \\
\text { (Kuhn, 1829) }\end{array}$ & MAZO, MNAE & $\begin{array}{l}\text { Scomber scombrus } \\
\text { Linnaeus }\end{array}$ & UK & AF382044 & $28 S$ & Olson et al. (2002) \\
\hline Kuhnia scombri & MAZO, MNAE & Scomber scombrus & & AJ228783 & $18 S$ & Littlewood et al. (1998) \\
\hline
\end{tabular}

* Abbreviations: DICL - Diclidophoridae, PARA - Parapedocotylinae, PEDO - Pedocotylinae, EURY - Eurysorchiinae, CHOR - Choricotylinae, DNAE - Diclidophorinae, MICR - Microcotylidae, MCAE - Microcotylinae, MAZO - Mazocraeidae, MNAE - Mazocraeinae.

in Entellan. Two specimens were serially sectioned $(6 \mu \mathrm{m}$ in thickness) and stained with hematoxyline-eosin.

Drawings were made with the aid of a drawing tube. Measurements are in micrometres $(\mu \mathrm{m})$ unless otherwise indicated and are given as range with standard deviation in parentheses. For scanning electron microscopy (SEM), two live specimens were fixed in alcohol $(80 \%)$, dehydrated through a graded ethanol series $(80 \%, 90 \%$, absolute alcohol), critically point dried (liquid $\mathrm{CO}_{2}$ as intermediate liquid) in a Samdri-780 A Tousimis and sputter-coated with gold. Samples were examined using a JEOL-JSM-T300 at an accelerating voltage of $15 \mathrm{kV}$. Terminology of clamp sclerites was used as defined for other diclidophorids (Euzet and Suriano 1975).

Newly collected specimens for molecular study were fixed with $99 \%$ ethanol. The $28 \mathrm{~S}$ rRNA gene, the V4 region of the $18 \mathrm{~S}$ rDNA gene as well the mitochondrial coxl gene were sequenced from five specimens of Parapedocotyle prolatili, four of Pedocotyle bravoi and four of $P$. annakohni from the type host the minor stardrum Stellifer minor (Sciaenidae). Available sequences from Choricotyle chrysophryii (van Beneden et Hesse, 1863), Diclidophora minor (Olsson, 1876), Diclidophora denticulata (Olsson, 1876), Diclidophora luscae capelanii (van Beneden et
Hesse, 1863) as well Kuhnia scombri were also included in the analysis (see Table 1 for GenBank accession numbers).

DNA was extracted from newly collected specimens using the QIAampTissue Kit (Qiagen, Hilden, Germany) following manufacturer's instructions. The DNA was then eluted into $50 \mu \mathrm{l}$ of nuclease-free water.

The 28S rDNA gene was amplified by polymerase chain reaction (PCR) using the forward primer C1 (5'-ACCCGCTGAATTTAAGCAT-3') and the reverse primer D2 (5'-TGGTCCGTGTTTCAAGAC-3') (Chisholm et al. 2001). The 18S rRNA gene was amplified with forward primer Sb3a (5'-GGAGGGCAAGTCTGGTGC-3') and the reverse primer A27a (5'-CCATACAAATGCCCCCGTCTG-3') following the protocol described by Hall et al. (1999). The coxl gene was amplified with forward L-CO1 (5'-TTTTTTGGGCATCCTGAGGTTTAT-3') and the reverse primer H-CO1 (5'-TAAAGAAAGAACATAATGAAAATG-3') (Verneau et al. 2009).

Each PCR reaction had a final volume of $35 \mu \mathrm{l}$ including: 5 standard units of GoTaq DNA polymerase (Promega, Madison, USA), $7 \mu 15 \times$ PCR buffer, $5.6 \mu \mathrm{MgCl}_{2}(25 \mathrm{mM}), 2.1 \mu \mathrm{lBS}$ $(10 \mathrm{mg} / \mathrm{ml}), 0.7 \mu \mathrm{l}$ of deoxynucleotide triphosphate (dNTP) $(10 \mathrm{mM}), 10 \mathrm{pM}$ of each primer and $7 \mu \mathrm{l}$ template DNA. Amplification for each molecular marker was done according to the 
protocols described by Chisholm et al. (2001), Hall et al. (1999) and Verneau et al. (2009) for the 28S rDNA, 18S rDNA gene and coxl gene, respectively. Double-stranded PCR products were cleaned using an E.Z.N.A. ${ }^{\circledR}$ Cycle-Pure Kit (Omega BioTek, Inc., Atlanta, USA), and both DNA strands were directly sequenced (Macrogen, Seoul, Korea; http://www.macrogen. com).

A $820 \mathrm{bp}$ fragment of the $28 \mathrm{~S}$ rDNA, $450 \mathrm{bp}$ fragment of the 18S rRNA and $440 \mathrm{bp}$ fragment for coxl were edited using ProSeq v 2.9 beta (Filatov 2002) and aligned with Clustal X (Larkin et al. 2007) using the default parameters. The distance analysis (p-distance and number of differences) was estimated using Mega v.5.0 (Tamura et al. 2011).

For the phylogenetic analyses, sequences of some diclidophorids available in the GenBank database, as well our own sequences from some diclidophorids from Chile, were included in the analysis (Table 1). Sequences of the mazocraeid monogenean Kuhnia scombri (28S and 18S rDNA) and Paramicrocotyle sp. ( $\operatorname{cox} 1)$ were used as outgroups. Since sequences from the GenBank database were always shorter than the sequences obtained in the present study, only $521 \mathrm{bp}$ fragment for the $28 \mathrm{~S}$ rRNA, $441 \mathrm{bp}$ for the $18 \mathrm{~S}$ rRNA and $415 \mathrm{bp}$ for coxl genes, respectively, were used.

The phylogenetic trees were constructed using the maximum likelihood (ML) method in Mega v.5.0 (Tamura et al. 2011) and by Bayesian inference (BI) using MrBayes v3.1.2 (Huelsenbeck and Ronquist 2005). To determine the model that yielded the best fit to our dataset, Mega v.5.0 (Tamura et al. 2011) was employed.

The results from the model test indicated that the HKY $+\mathrm{G}$ model was the most appropriate evolution model for this dataset. Consequently, we incorporated this model of nucleotide evolution in ML and BI analyses. For the ML tree, a heuristic search using nearest neighbour interchange and bootstrap resampling (Felsenstein 1985) was applied to assess the support for individual nodes using 1000 bootstrap replicates. Bayesian phylogenetic analyses were conducted using four simultaneous Markov chains running 5000000 generations sampling each 1000 generations. The first 1250 generations (burn-in) were discarded as suggested by Felsenstein (1985) and the 1250 random generations also were discarded. The remaining 2500 trees sampled were used to construct a $50 \%$ majority-rule consensus tree. Nodal support values (posterior probabilities) were calculated as the percentage of the 2500 sampled trees containing the node.

\section{RESULTS}

Family Diclidophoridae Cerfontaine, 1895

\section{Parapedocotylinae new subfamily}

Diagnosis. Body cylindrical. Haptor with four pairs of clamp of diclidophorid type. First pair of clamps in posterior extension of haptor, non-pedunculate. Three pairs of pedunculate clamps (pairs 2-4) different in sclerite armature from pair 1. Genital corona present. Oesophagus short, intestinal crura extending into haptor or not. Testes in two rows in median field posterior to ovary. Genital atrium armed. Ovary tubular, curved from right to left (inverted U-shaped). Seminal receptacle preovarian. Vagina absent. Genitointestinal canal present. Vitellarium not extending to haptor. Parasite of gills of marine fish (Pinguipedidae).
Remarks. Among the Diclidophoridae, the Pedocotylinae is unique by having a haptoral projection bearing the first pair of clamps. All nominal species of Pedocotyle are parasites of marine sciaenid fishes and are characterised by a non-functional first pair of clamps with pairs 2-4 functional; sclerite structure for the first pair of clamp cannot be resolved (Sproston 1946, Luque-Alejos and IannaconeOliver 1989). In contrast, the first pair is well developed and functional in the Parapedocotylinae, whereas pairs 2-4 are apparently non-functional. The seminal receptacle is preovarian in the new subfamily rather than postovarian in the Pedocotylinae. The morphological characteristics of our specimens as well as the results of molecular analyses (see below) justify the erection of this new subfamily.

\section{Parapedocotyle gen. $n$.}

Diagnosis. With characteristics of Parapedocotylinae. Body long, fusiform, bearing extended haptor. Four pairs of clamps of diclidophorid type. First pair of clamp nonpedunculate at end of haptoral appendix. Clamp pairs 2 to 4 near proximal end of haptor, pedunculate, strongly modified. Sclerites As (axial sclerite of anterior jaw) and Al (lateral sclerite of anterior jaw) bearing lamellar projections covering almost all posterior quadrant. Intestinal caeca and vitellarium not extending to haptor. Testes arranged in two rows. Copulatory organ anterior to intestinal bifurcation, armed with curved hooks with bifid base. Seminal receptacle preovarian.

Type and only species: Parapedocotyle prolatilisp.n. Ety mology: Parapedocoyle refers to morphological similarity with Pedocotyle.

\section{Parapedocotyle prolatili sp. $\mathrm{n}$.}

Figs. 1-7

Diagnosis (based on 16 stained and mounted specimens and 2 serially sectionned specimens): Body fusiform, 4.9-12.9 $\mathrm{mm}(7.8 \pm 2.1 \mathrm{~mm})$ in total length, $0.52-1.65 \mathrm{~mm}(0.92 \pm 0.33 \mathrm{~mm})$ in maximum width at level of ovary (Fig. 1). Haptor 2.0-5.4 mm (3.4 $\pm 0.9 \mathrm{~mm})$ long and 110-330 (210 \pm 60$)$ wide, bearing four pairs of clamps (Fig. 2). Clamp pair 1 non-pedunculate at terminal end of haptor, 115-207 (155 \pm 26$)$ long and 130-212 $(170 \pm 30)$ wide. Structure of first pair of clamps typical of diclidophorids (Fig. 3). Clamps of pairs 2 to 4 at end of short peduncle, 118-215 (150 \pm 18$)$ long and 130-230 $(160 \pm 34)$ wide and modified, sclerites $O$ (median sclerite of posterior jaw), Ps2 (sclerite bordering axial portion of the posterior jaw) and P12 (sclerite bordering lateral portion of posterior jaw) typical for diclidophorids, but sclerites As (axial sclerite of anterior jaw) and Al (lateral sclerite of anterior jaw) strongly modified, bearing well developed lamellar projection covering almost all posterior quadrants (Fig. 4). Two pairs of larval hooks of different sizes at end of haptor, between non-pedunculate clamps (Fig. 5). First pair of clamp serving a main attachment organ, pair 2 to 4 almost non-functional (in situ observation of live specimens). 

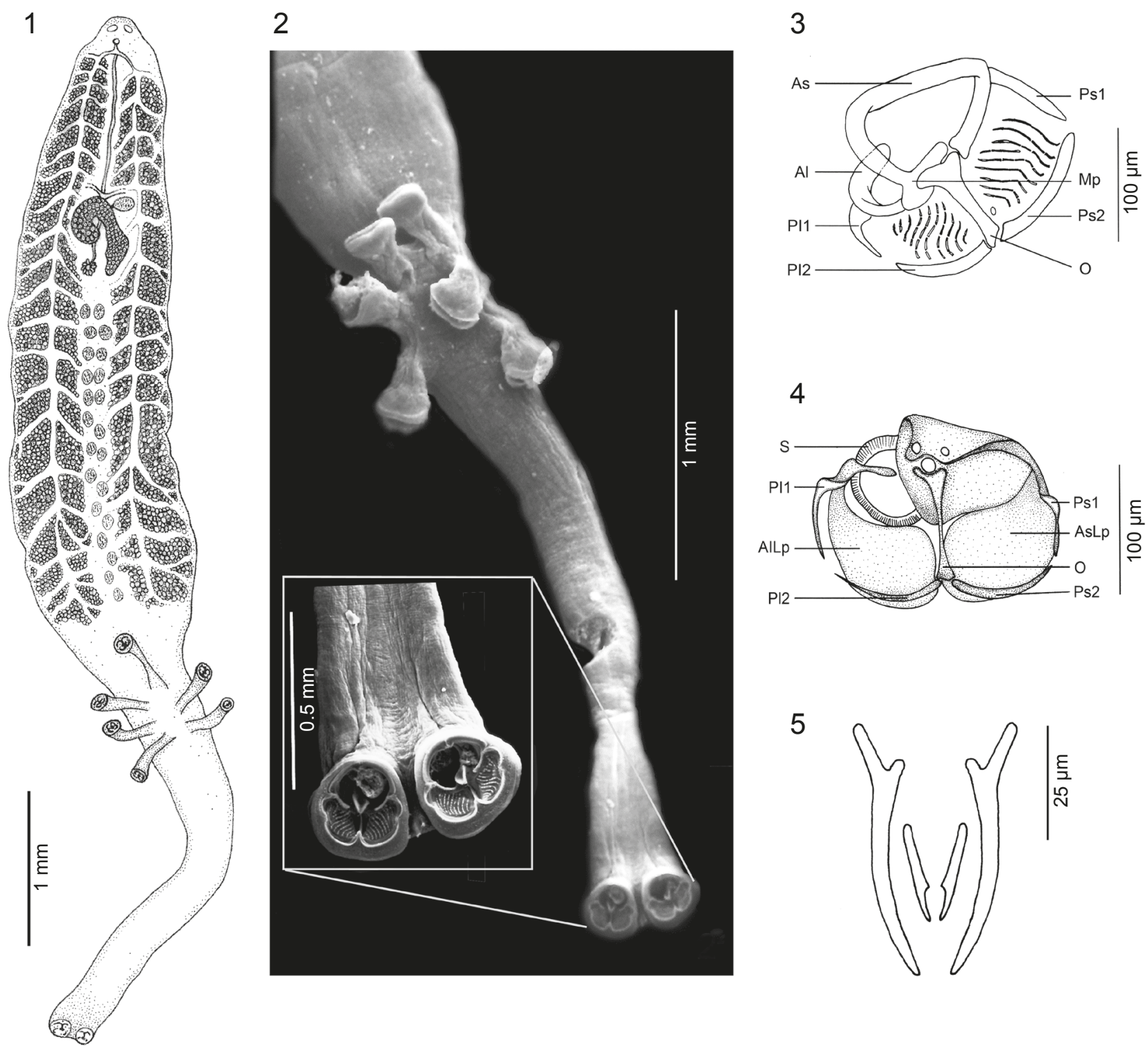

5

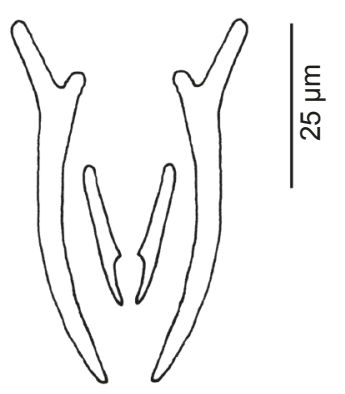

Fig. 1. Parapedocotyle prolatili gen. n. et sp. n. from Prolatilus jugularis, holotype (USNPC 101156), ventral view. Fig. 2. Scanning electron micrographs of the haptor and clamp pair 1 (inset). Fig. 3. Armature of clamp pair 1. Fig. 4. Armature of clamp pairs 2-4. Fig. 5. Larval hooks. Abbreviations: Al - lateral sclerite of anterior jaw; AlLp - lamellar projection of sclerite $\mathrm{Al}$; As - axial sclerite of anterior jaw; AsLp - lamellar projection of sclerite As; $\mathrm{Mp}$ - posterior section of median sclerite; $\mathrm{O}$ - median sclerite of posterior jaw; Pl1 - sclerite bordering lateral portion of posterior jaw (dorsal); Pl2 - sclerite bordering lateral portion of posterior jaw (ventral); Ps 1 - sclerite bordering the axial portion of posterior jaw (dorsal); Ps2 - sclerite bordering axial portion of posterior jaw (ventral).

Oral suckers oval, 45-93 (71 \pm 15$)$ long and 34-67 $(56 \pm 9)$ wide. Mouth terminal; pharynx ovoid, 54-102 (77 \pm 4$)$ long, $45-83(65 \pm 11)$ wide. Intestinal bifurcation posterior to male copulatory organ. Testes $21-27$, in 2 rows, $88-120(105 \pm 11)$ in diameter on average, spherical, postovarian, interceacal. Male copulatory organ 15-52 (31 \pm 10$)$ in diameter, armed with 6 to 9 (mode $=7$ ) curved hooks, each having bifid base (Fig. 6). Ovary tubular, curved from right to left. Ootype postovarian (Fig. 7). Oviduct originating from left side of ovary, with short ascending section, descending near midline of body proper, receiving main vitelline and seminal ducts.
Seminal receptacle ovate, preovarian. Genitointestinal canal originating anterior to junction of oviduct and vitelline duct. Vitelline follicles coextensive with intestinal caeca. Eggs not observed.

Ty pe host: Pacific sandperch Prolatilus jugularis (Valenciennes) (Perciformes: Pinguipedidae).

Site of infection: Gill filaments.

Type locality: Coquimbo $\left(30^{\circ} 56^{\prime} \mathrm{S} ; 71^{\circ} 20^{\prime} \mathrm{W}\right)$, Province of Coquimbo, northern Chile.

Specimens deposited: Holotype (1 stained, wholemounted specimen) in the United States National Parasite Collection, Beltsville, USA (USNPC 101156); paratypes 
Oliva et al.: Parapedocotylinae, new subfamily of Diclidophoridae

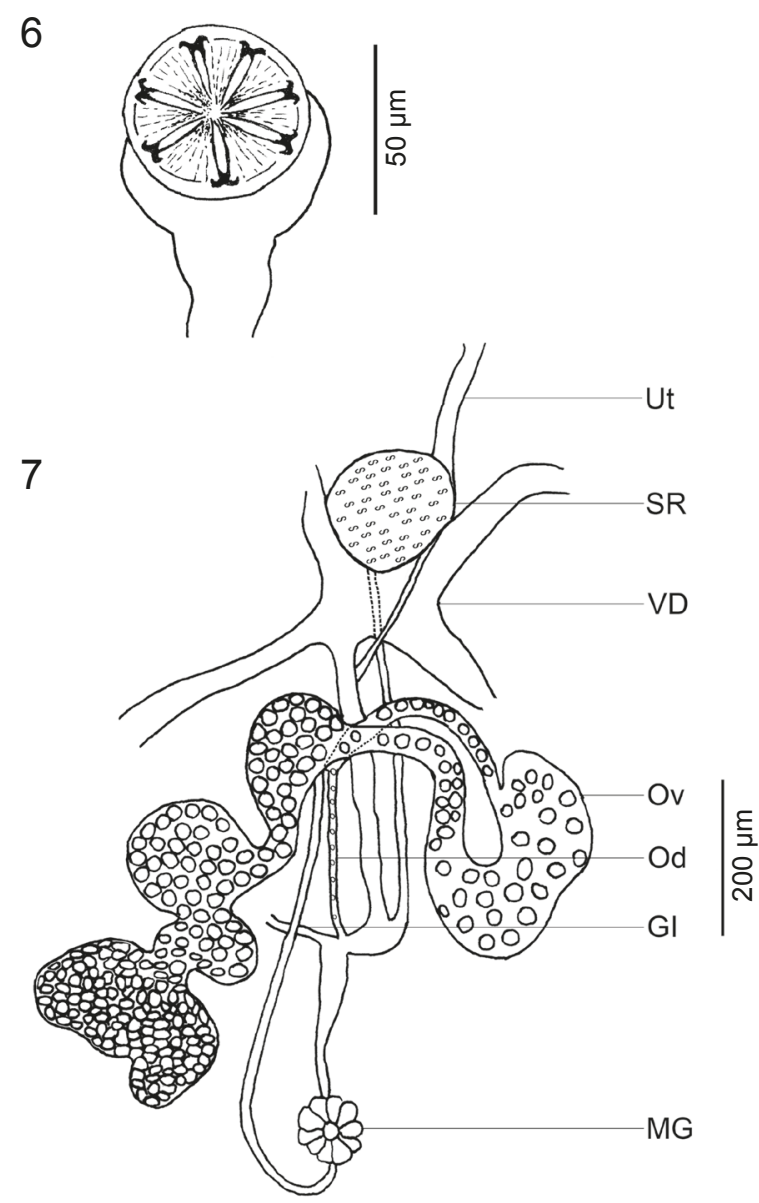

Fig. 6, 7. Parapedocotyle prolatili gen. n. et sp. n. from Prolatilus jugularis Fig. 6. Male copulatory organ. Fig. 7. Composition of female genitalia (ventral view) from serial sections. $A b$ breviations: Ut - uterus; SR - seminal receptacle; VD - vitelline ducts; Ov - ovary; Od - oviduct; GI - genito-intestinal canal; MG - Mehlis' gland.

(2 stained, whole-mounted specimens) in USNPC (101157) and in the Helminthological Collection, Institute of Parasitology, Biology Centre of the Czech Academy of Science, České Budějovice, Czech Republic (IPCAS M-549).

Ety mology: Specific name refers to host genus.

\section{Molecular analysis}

No mutations were detected among the five sequences of Parapedocotyle prolatili, four sequences of Pedocotyle bravoi and Pedocotyle annakohni of both, the 18S and $28 \mathrm{~S}$ rRNA genes. Intraspecific variability in cox 1 sequences of $P$. prolatili and $P$. bravoi was low: 0.4 and $0.6 \%$, respectively (amplification of the cox 1 gene for $P$. annakohni was unsuccessful).

For $18 \mathrm{~S}$ rDNA the lower divergence was observed between $P$. prolatili and P. sarmientoi (4.7\%, i.e. $20 \mathrm{bp})$ compared to $P$. prolatili and $K$. scombri $(17.8 \%$, i.e. $76 \mathrm{bp})$. Divergence between the new species and $P$. bravoi and P. annakohni was $12.0 \%$ (51 bp) and $12.2 \%$ (52 bp), respectively. Lower divergence for $28 \mathrm{~S}$ rDNA was found

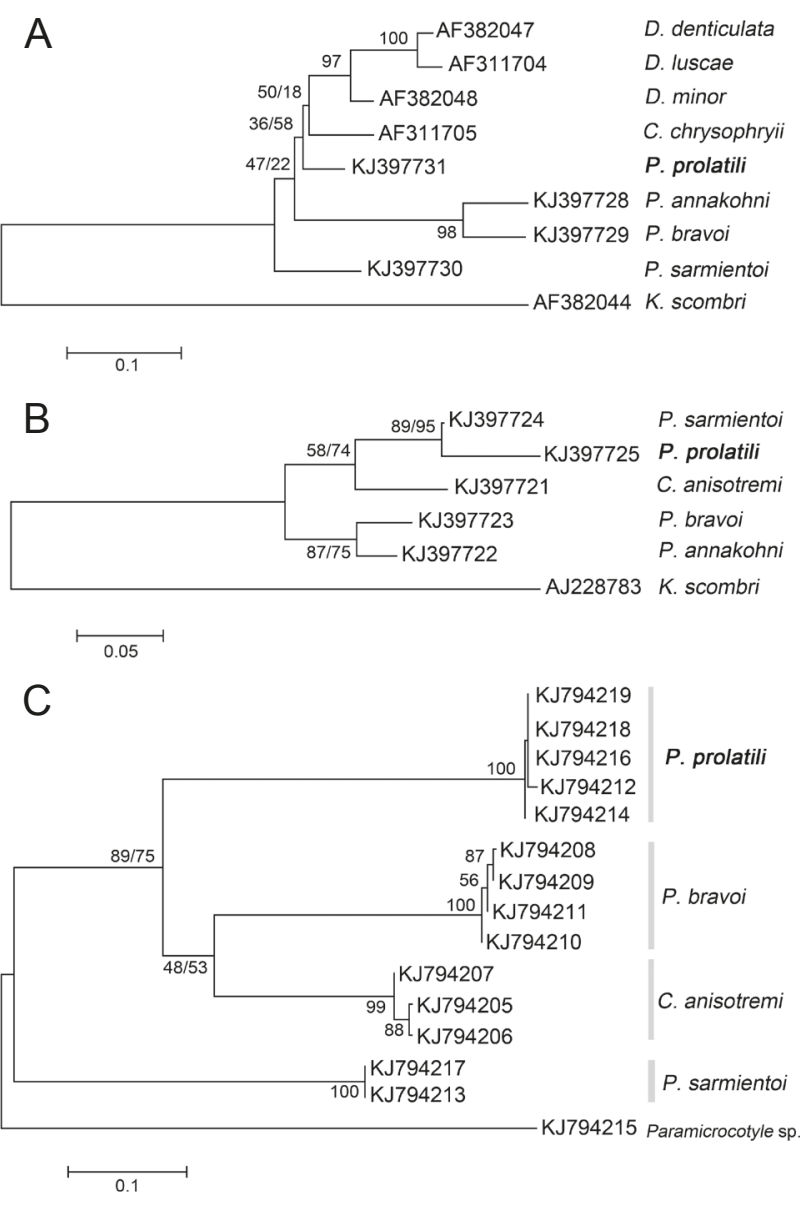

Fig. 8. Phylogenetic tree based on $28 \mathrm{~S}$ rDNA (A), $18 \mathrm{~S}$ rDNA (B) and cox 1 (C) gene. All trees were inferred by Mr Bayes (left value in nodal support) and maximum likelihood with $\mathrm{HKG}+\mathrm{G}$ model (right value in nodal support).

between $P$. prolatili and Choricotyle cf. chrysophryii $(7.4 \%$, i.e. $35 \mathrm{bp})$ and the higher between $P$. prolatili and Kuhnia scombri (29\%, i.e. 137 bp). Divergence between the new species and $P$. bravoi and P. annakohni was $16.3 \%$ (77 bp) and 15.7\% (74 bp), respectively. The lower divergence for the cox 1 gene was between $P$. prolatili and Choricotyle anisotremi $(20.6 \%, 84-88 \mathrm{bp})$ compared to P. prolatili and Paramicrocotyle sp. (25.3\%, 104-106 bp). Divergence between the new species and $P$. bravoi reached 23.1\% (94-98 bp) (Fig. 8).

\section{DISCUSSION}

Among the Diclidophoridae, the Pedocotylinae is unique by the peculiar structure of the haptor, bearing the first pair of clamps non-pedunculate, situated on the posterior extension of the haptor. In the only known genus of this subfamilly, Pedocotyle, the first pair is not functional and defined as in an immature and unemerged condition (see Sproston 1946), whereas pairs 2-4 are well developed and functional, but an accessory sucker is absent 
and vitelline follicles extend to the haptor (Sproston 1946, Luque-Alejos and Iannacone-Oliver 1989).

In contrast, the specimens described herein have a well developed first pair of clamps, whereas pairs 2-4 are apparently not functional, as indicated by the small size of these structures and also confirmed by observation of live specimens in situ. In addition, vitelline follicles do not extend to the haptor. The armature of clamps pair 2-4 is unique among the diclidophorids; specifically the lamellar projection of sclerites As and Al covering almost entirely the posterior quadrant has not been described (see Mamaev 1976).

The reported for any other diclidophorid species of the Pedocotylinae are gill parasites of sciaenid fishes (Spros- ton 1946, Hargis 1955, Luque-Alejos and Iannacone-Oliver 1989), whereas the new species is a parasite of a pinguipedid. Its characteristics, in particular the structure of the haptor, which are unique among the Diclidophoridae, justify the erection of the new subfamily. Molecular data inferred from partial sequences of three genes also demonstrate that species of the Pedocotylinae and Parapedocotylinae are not closely related.

Acknowledgements. This study was financed by the National Fund for Science and Technology (FONDECYT-Chile), Postdoctoral Grant No. 3060054 to MTG. Lidia Sánchez (Museo de Historia Natural Universidad Nacional Mayor de San Marcos, Lima, Peru) kindly provided specimens of Pedocotyle bravoi and P. annakohni.

\section{REFERENCES}

Chisholm L., Whittington I., Morgan J., Adlard R. 2001: The Calicotyle conundrum: do molecules reveal more than morphology? Syst. Parasitol. 49: 81-87.

Euzet L., Suriano D.M. 1975: Orbocotyle marplatensis n. g., n. sp. (Diclidophoridae) monogène parasite branchial de téléostéens marins du genre Prionotus (Triglidae) en Argentine. Bull. Mus. Natl. Hist. Nat. (Zool.) 192: 11-22.

Felsenstein J. 1985: Confidence limits on phylogenies: an approach using the bootstrap. Evolution 39: 783-791.

Filatov D. 2002: Proseq: a software for preparation and evolutionary analysis of DNA sequence data sets. Mol. Ecol. Notes 2: $621-624$

Hall K.A., Cribb T.H., Barker S.C. 1999: V4 region of small subunit rDNA indicates polyphyly of the Fellodistomidae (Digenea) which is supported by morphology and life-cycle data. Syst. Parasitol. 43: 81-92.

Hargis W.J. 1955: Monogenetic trematodes of Gulf of Mexico fishes. Part IX. The family Diclidophoridae Fuhrmann, 1928. Trans. Am. Microsc. Soc. 74: 377-388.

Huelsenbeck J.P., RonQuist F. 2005: Bayesian analysis of molecular evolution using MrBayes. In: R. Nielsen (Ed.), Statistical Methods in Molecular Evolution. Springer, New York, pp. 183-232.

Jovelin R., Justine J.-L. 2001: Phylogenetic relationships within the polyopisthocotylean monogeneans (Platyhelminthes) inferred from partial 28S rDNA sequences. Int. J. Parasitol. 31: 393-401.

Larkin M.A., Blackshields G., Brown N.P., Chenna R., McGettigan H.P., McWilliam A., Valentin F., Wallace I.M., Wilm A., Lopez R., Thompson J.D., Gibson T.J.,

Received 17 May 2014
Higgins D.G. 2007: Clustal W and Clustal X version 2.0. Bioinformatics 23: 2947-2948.

Littlewood D.T.J., Rohde K., Clough K.A. 1998: The phylogenetic position of Udonella (Platyhelminthes). Int. J. Parasitol. 28: $1241-1250$

Luque-Alejos J., Iannacone-Oliver J. 1989: Pedocotyle annakohni n. sp. y Pedocotyle bravoi n. sp. (Monogenea: Diclidophoridae), parasitos de Stellifer minor (T.) (Teleostei: Sciaenidae) en la costa Peruana. Rev. Iber. Parasitol. 49: 301-306.

Mamaev Y.L. 1976: [The system and phylogeny of monogeneans of the family Diclidophoridae]. Trudy Biol. Pochvenn. Inst. Vladivostok, new series, 35: 57-80. (In Russian.)

Olson P.D., Littlewood D.T.J. 2002: Phylogenetics Phylogenetics of the Monogenea - evidence from a medley of molecules. Int. J. Parasitol. 32: 233-244.

Sproston N.G. 1946: A synopsis of the monogenetic trematodes. Trans. Zool. Soc. London 25: 185-600.

Tamura K., Peterson D., Peterson N., Stecher G., Nei M., Kumar S. 2011: MEGA5: Molecular evolutionary genetics analysis using maximum likelihood, evolutionary distance, and maximum parsimony methods. Mol. Biol. Evol. 28: 2731-2739.

Verneau O., Du Preez L., Laurent V., Raharivololoniaina L., Glaw F., Vences M. 2009: The double odyssey of Madagascan polystome flatworms leads to new insights on the origins of their amphibian hosts. Proc. Roy. Soc., Biol. Sci. 276: $1575-1583$.

Yamaguti S. 1963: Systema Helminthum. Volume IV. Monogenea and Aspidocotylea. Interscience Publisher, New York, 699 pp.

Accepted 2 July 2014 